\title{
RISK FACTORS FOR PREMATURE BIRTH IN INDONESIA
}

\author{
Hafiza Ajeng Dianing Sukma ${ }^{1}$, Sagar Tiwari \\ ${ }^{1}$ Faculty of Public Health, Universitas Airlangga, 60115 Surabaya, East Java, Indonesia \\ ${ }^{2}$ Central hospital, Chitwan, Nepal \\ Corresponding Author: Hafiza Ajeng Dianing Sukma \\ E-mail: hafiza.ajeng.dianing-2016@fkm.unair.ac.id
}

\begin{abstract}
Indonesia is currently taking on the challenge of the relatively high number of neonatal deaths influencing maternal and child health. Premature birth is the most significant contributor to the number of neonatal deaths. The occurrence of premature birth is motivated by various risk factors. Knowing the magnitude of the relationship between several risks, namely maternal age, location, parity, and maternal smoking habits with preterm birth incidents was the aim of this study. The 2017 Indonesian Demographic and Health Survey (IDHS) was a source of data used. This study employed a cross-sectional approach and then processed the results with univariate and bivariate tests. The results showed a relationship between maternal age and residential area with the premature birth, where mothers under 20 years and over 35 years had a higher probability of giving birth prematurely. The area of residence, which was divided into rural and urban, also had a relationship with premature birth. The parity and smoking habits showed no association with preterm birth. Education, Antenatal Care (ANC), and other various efforts to emphasize maternal and child health care during pregnancy need to be continuously improved to reduce preterm birth rates in Indonesia.
\end{abstract}

Keywords: prematurity, preterm birth, risk factors

\begin{abstract}
ABSTRAK
Jumlah kematian neonatal yang terbilang masih tinggi merupakan salah satu permasalahan kesehatan ibu dan anak dimana hingga saat ini menjadi tantangan negara Indonesia. Kelahiran prematur merupakan penyumbang terbesar jumlah kematian neonatal. Terjadinya kelahiran prematur pada dasarnya dilatar belakangi oleh berbagai faktor risiko. Diketahuinya besaran keterkaitan antara beberapa risiko yaitu usia ibu, daerah, paritas, dan kebiasaan merokok ibu dengan kejadian kelahiran prematur merupakan tujuan dari penelitian. IDHS pada tahun 2017 merupakan sumber data dari penelitian dengan pendekatan cross sectional kemudian diolah menggunakan uji univariat dan bivariat. Hasil penelitian menunjukkan terdapat keterkaitan antara usia ibu dan daerah tempat tinggal dengan kejadian kelahiran prematur dimana usia ibu dibawah 20 tahun dan diatas 35 tahun memiliki kemungkinan lebih tinggi untuk melahirkan secara prematur. Daerah tempat tinggal juga memiliki keterkaitan dimana dibagi menjadi pedesaan dan perkotaan. Hasil uji dari variabel paritas dan kebiasaan merokok menunjukkan tidak adanya hubungan dengan kejadian kelahiran prematur. Edukasi, Antenatal Care $(A N C)$, dan berbagai upaya penekanan berkaitan dengan pemeliharaan kesehatan ibu dan anak semasa kehamilan perlu untuk terus ditingkatkan agar dapat menurunkan angka kelahiran prematur di Indonesia.
\end{abstract}

Kata Kunci: prematuritas, kelahiran prematur, faktor risiko

\section{INTRODUCTION}

The high number of neonatal death is one of the health problems, especially those related to maternal and child health, faced by Indonesia today. Neonatal Mortality Rate (NMR) offers the number per 1,000 live births. According to the Indonesian Ministry of Health (2018), in 2017, Indonesia had 15 neonatal deaths per 1,000 live births. There had been a decrease of 4 deaths compared to the number of neonatal deaths in 2012 . However, it remains necessary to continuously facilitate the decline to achieve the Sustainable Development Goals (SDGs) target. This target aims to achieve comparative results between premature births and live births of 0.0007 by 2030 . One of the various problems that cause neonatal death is maternal and child health problems during 
pregnancy. The period from the fertilization process to the fetus birth is known as pregnancy (Fatimah and Nuryaningsih, 2017). Generally, during pregnancy, the expectation was to have a reasonable or normal gestation period. However, there could be abnormal conditions experienced by some mothers during pregnancy called pregnancy complications. Different kinds of pregnancy complications happen in each trimester. Also, pregnancy complications may occur more than once during a pregnancy. According to Manuaba, Manuaba, and Manuaba (2009), there are seven kinds of pregnancy complications in the third trimester, where the baby's condition should be approaching the time of normal pregnancy complications, that premature birth could occur.

Preterm birth or prematurity is one of the most significant contributors to the high NMR. The World Health Organization (WHO) (2012) stated that preterm birth is the most significant contributor in neonatal mortality and ranked second as a cause of mortality under-five years of age after pneumonia. The WHO also stated that Indonesia was in the $9^{\text {th }}$ position for the highest number of preterm births globally. The WHO statement is supported by the research results of Sari and Syarif (2016), where preterm birth was proven to have a relationship with neonatal mortality in Indonesia. Krisnaldi (2009), stated that the risk of death for babies born prematurely was $7,000 \%$ compared to normal ones. The incomplete organs of premature babies cause a lack of ability to adapt to life outside the womb if compared to babies who were not born premature. This showed that preterm births in Indonesia need to be taken into account to reduce the IMR number and achieve its target.

Usually, pregnancy would last between 37-41 weeks. However, in some cases, there could be an abnormality of the gestation period which becomes shorter, which is known as preterm birth. Premature birth, an abnormal birth, occurs when the gestational age is faster than the normal length of 20 to 37 weeks (Koniyo, Hakim, and Arsin, 2012). According to WHO (2012), prematurity is an infant born alive with a gestation period of $\leq 37$ weeks. Premature birth according to the WHO (2012) could be grouped into three subcategories based on gestational age at birth, which are highly preterm (gestational age $\leq 27$ weeks), very preterm (gestational age $28-\leq 31$ weeks), and moderate to late preterm (gestational age 32 to $\leq 36$ weeks). Anasari and Pantiawati (2016) stated that the characteristics of premature babies include body length of $\leq 45 \mathrm{~cm}$, body weight at birth $\leq$ 2500 grams, a head circumference of $<33 \mathrm{~cm}$, and a chest circumference of $<30 \mathrm{~cm}$. Premature birth could cause a variety of health problems for the babies in the near future or long term, and the most fatal one is infant mortality. According to Anasari and Pantiawati (2016), premature birth could occur repeatedly in mothers who have previously experienced it. Therefore, it remains necessary to know the risk factors associated with preterm birth as a preventive measure aimed at reducing the number of incidents.

According to the WHO (2012), premature birth could be caused by maternal factors such as repeated pregnancies, infections during pregnancy, chronic conditions of the mother, and heredity. Premature birth could also be caused by the mothers' lifestyle, for example diet or smoking habits. According to Noriani, Putra, and Karmaya (2015), preterm birth risks are divided into two categories. The first category is internal factors, where the risks originate from the mother's body such as genetics or congenital conditions, autoimmune, stress, and physical conditions. The second category was external factors coming from outside the mother's body, including lifestyle, social and economic, diet and nutrition in food consumed, health care, environmental conditions (e.g., air pollution), and exposure to cigarette smoke.

According to Murad et al. (2017), most of the risk factors associated with preterm births are heredity, infection during pregnancy, and Body Mass Index (BMI). Maidartati and Parsaulian (2015) stated that mothers need to avoid exposure to cigarettes during pregnancy because its contents-carbon monoxide and nicotine affect the baby's birth weight and possibly cause premature birth. The demographic risk factors that have the potential to influence preterm birth include maternal age, race, and education according (Tepper et al., 2012). 
This study aimed to identify a relationship between maternal age, residential area, parity, smoking behavior, and premature birth as well as knowing whether there is a relationship between maternal age, area, parity, and smoking behavior with preterm birth and its magnitude.

\section{METHODS}

This study was categorized as the nonreactive study using a cross-sectional design approach for one time data collection. The data source was retrieved from the 2017 Indonesia Demographic and Health Survey (IDHS). The research subjects were mothers who gave birth during the survey in Indonesia.

The independent variables investigated were maternal age, residential area, parity, and smoking behavior. The dependent variable was preterm birth. Following the selection of these variables, this study involved a sample of 7,532 mothers who gave birth at least once at the time of data collection.

To be more specific, finding the number and magnitude of the relationship between variables was the aim of this study. Understanding each variable's frequency is necessary to determine the importance of the relationship between mother's age, residential area, maternal parity, and maternal smoking habits with preterm birth.

\section{RESULTS}

\section{Univariate Analysis}

Univariate analysis was intended to determine the frequency of each variable. The data were collected from 7,532 respondents who were mothers that had given birth. As many as 7,532 respondents were then sorted according to the characteristics of the variables.

Table 1 shows as many as $5.2 \%$ of the respondents had experienced premature birth, while the rest $(94.8 \%)$ did not. Maternal age before being grouped into three groups shows most respondents' age were $\leq 31$ years. After the respondents' age group was grouped, the most frequent age group of respondents seen was $20-$ 34 years $(67.4 \%)$, followed by the age group $\geq 35$ years $(29.6 \%)$, with the least frequent at $\leq 19$ years (3\%). For residence, the largest frequency is that of respondents who live in urban areas $(51.9 \%)$, the rest living in rural areas (47.3\%). The respondents' parity before being grouped into two groups had the highest frequency of 2,068 (parity 1). After being grouped, there was an insignificant difference between the non-risky parity group (52.8\%) and the risky parity group (47.2\%). Lastly, it could be seen that most respondents did not smoke (98.2\%), while a small number did $(1.8 \%)$.

Table 1. Variable Frequency of Premature Birth, Maternal Age, Region, Parity, and Smoking Behavior.

\begin{tabular}{lcc}
\hline Characteristics & f & \% \\
\hline Premature Birth & & \\
\hline Yes & 389 & 5.2 \\
Not & 7,143 & 94.8 \\
\hline Mother's Age & & \\
\hline$\leq 19$ years & 179 & 2.4 \\
20 - 34 years & 4,941 & 65.6 \\
$\geq 35$ years & 2,412 & 32 \\
\hline Residential Area & & \\
\hline Rural & 3,628 & 48.2 \\
Urban & 3,903 & 51.8 \\
\hline Parity & & \\
\hline Risky & 3,553 & 47.2 \\
Not Risky & 3,979 & 52.8 \\
\hline Smoking Behavior & & \\
\hline Smoker & 132 & 1.8 \\
Non smoker & 7,400 & 98.2 \\
\hline
\end{tabular}

\section{Bivariate Analysis}

Bivariate analysis was carried out after the univariate analysis. The relationship between the independent and dependent variables in the study was based on the bivariate analysis result.

Table 2 presents that the relationship between maternal age and preterm birth was divided into three categories: $\leq 19$ years, 2034 years, and $\geq 35$ years $(\mathrm{p}=0.030)$, meaning the $\mathrm{HO}$ was rejected. This study also found residential area divided into urban and rural categories was related to preterm birth $(\mathrm{p}=$ 0.036). The results of statistical test by parity categorized as risky and not risky was $(p=0.348)$, indicating that the H0 was 
accepted. The result of the statistical test by smoking behavior variable i.e., smoker and non-smokers was $(\mathrm{p}=0.504)$, concluding that the H0 was accepted.

Table 2. Analysis Results of the Relationship between Maternal Age, Region, Parity, and Smoking Behavior with Premature Birth

\begin{tabular}{|c|c|c|c|c|c|c|}
\hline \multirow[t]{3}{*}{ Variables } & & \multicolumn{4}{|c|}{ Premature Birth } & \multirow{3}{*}{$P$} \\
\hline & & \multicolumn{2}{|c|}{ Yes } & \multicolumn{2}{|c|}{ Not } & \\
\hline & & $\mathbf{n}$ & $\%$ & $\mathbf{n}$ & $\%$ & \\
\hline \multirow[t]{3}{*}{ Mother's Age } & $\leq 19$ years & 11 & 0.2 & 168 & 2.2 & 0.030 \\
\hline & $20-34$ years & 277 & 3.7 & 4664 & 61.9 & \\
\hline & $\geq 35$ years & 101 & 1.3 & 2311 & 30.7 & \\
\hline \multirow[t]{2}{*}{ Residential Area } & Rural & 208 & 2.8 & 3420 & 45.4 & 0.036 \\
\hline & Urban & 181 & 2.4 & 3723 & 49.4 & \\
\hline \multirow[t]{2}{*}{ Parity } & Risky & 174 & 2.3 & 3379 & 44.9 & 0.348 \\
\hline & Not Risky & 215 & 2.8 & 3764 & 50.0 & \\
\hline \multirow{2}{*}{ Smoking Behavior } & Smoker & 9 & 0.1 & 123 & 1.6 & 0.504 \\
\hline & Non smoker & 380 & 5.1 & 7020 & 93.2 & \\
\hline
\end{tabular}

\section{DISCUSSION}

As the data used were secondary data, the researcher did not have control on data collection and data quality.

\section{Relationship between Maternal Age and Premature Birth}

Maternal age is one of the variables that needs attention. Table 2 shows that mothers aged 20-34 years experienced the highest number of preterm births amounting to 277 cases. While, 112 preterm births occurred to mothers at risky age of $\leq 19$ years and $\geq 34$ years. The mother's age was confirmed to be associated with preterm birth $(\mathrm{p}=0.030)$.

According to Maita (2012), mothers aged $<20$ years are at risk because their reproductive organs have not been fully formed to conceive or give birth. Meihartati (2016) stated that this could cause reduction of nutrition from mother to fetus. Women aged $>34$ years are also at a risk category due to decreasing function and endurance of reproductive organs (Maita, 2012).

The results were directly proportional to the research of Wahyuni and Rohani (2017), in which maternal age had a relationship with preterm birth. According to the researchers mentioned, the preterm birth incidents had a relationship and was influenced by the mother's age. It was supported by the fact that the physical reproductive organs of mothers aged $<20$ years were not yet fully formed. This conclusion is also directly similar to research by Meihartati (2016) that showed pregnancy at an early age had a significant relationship and affected preterm birth. In the same way, those aged >34 years had more risk of complications due to a decreased physical condition. The physical condition refers to the health and ability of the reproductive organs.

\section{Relationship between Residential Area and Premature Birth}

Table 2 explains that mothers who lived in rural areas (208 respondents) were more likely to experience preterm birth than those in urban areas (181 respondents). The statistical analysis between residential area and preterm labor showed a p-value of 0.036 indicating a relationship between the variables.

According to Senewe and Sulistyowati (2004), regional factors are related to education, economy, and existing facilities in an area. The residence area could also be related to the environment that plays a stressor for the mother during pregnancy (Herlina, Desmiwarti, and Edison, 2016).

Research conducted by Sulistiarini and Berliana (2016) showed that residential area had a relationship and influence on the occurrence of preterm birth. Researchers have indicated that the access and availability of health facilities and health workers between urban and rural areas might have differences. The results of this study are suitable with the research above. 
The relationship between residential area and premature birth was assumed to deal with the environmental factors. These may include socio-economic conditions, environmental conditions, e.g., pollution levels, water conditions, and others. It could also be related to access to health services and the presence of health workers to help mothers.

\section{Relationship between Parity and Premature Birth}

Based on Table 2, it could be seen that 174 respondents who experienced premature birth had a parity of 1 or 4 categorized as risky. As many as 215 respondents with a parity of 2 or 3 were categorized as non-risky. The number of respondents having risky parity and never experiencing premature birth amounted to 3,379 mothers, while the parity of 3,374 respondents was not at risk. A p-value of 0.348 showed that parity had no relationship with preterm birth.

According to Manuaba, Manuaba, and Manuaba (2007), parity is classified into three groups. The first group, primiparous, is determined by the first time a woman has given birth to a baby large enough to live outside. The second group, multiparous, is when a woman has given birth as many as 2-5 times. Third, grand multipara is when a woman has given birth six or more times.

According to Pinontoan and Tombokan (2015), from a perspective of maternal and child health, the safest parity is $2-3$ births. Parity 1 and $\geq 4$ are at a higher risk than parity $2-3$.

The results of this study are inversely related to Wahyuni and Rohani's research (2017) which found parity had a significant relationship with preterm birth. However, the results are different from the research of Paembonan, Ansar, and Arsyad (2013) highlighting that the parity variable had no relationship with preterm birth. The researchers stated that other factors have caused preterm birth.

\section{The Relationship between Smoking Behavior and Premature Birth}

Individual behaviors could indicate health status. This study used smoking as a subvariable behavior. Table 2 explains that the non- smoking group experienced 380 premature births, while nine mothers who smoked experienced premature birth. The rest either smokers or non-smokers did not experience premature birth.

It was determined that a p-value of 0.504 suggested no relationship between mother's smoking behavior and preterm labor. Due to limited data, this study only listed mothers as perpetrators or active smokers. Despite this definition, mothers can also become passive smokers if they are exposed to the secondhand smoke from others. Being a passive smoker could also endanger maternal and child health. Results could be different if passive smoking mothers are included as Noriani, Putra, and Karmaya (2015) discovered that cigarette smoke exposure in the house was related to premature birth. Researchers have stated that exposure to cigarette smoke harms the mother and fetus's health during pregnancy because the compounds in cigarettes can poison the fetus.

Nicotine and tar in cigarettes are dangerous for pregnant women and affect the mother and consequently the child. Mothers exposed to secondhand smoke from the environment or smoking during pregnancy have the potential to develop pregnancy complications, such as underweight babies, premature births, perinatal mortality, impaired fetal development, and reproductive health of the mother and fetus (Astuti, Susanti, and Elista, 2016).

\section{CONCLUSIONS AND SUGGESTIONS}

\section{Conclusions}

There were various causes of neonatal and infant mortality. One of the most significant contributors is preterm birth. As suggested, mother's age and residential area had a relationship with preterm birth. Living in rural and urban areas differs in terms of how mothers have access to health facilities or health workers, which could suppress the occurrence of preterm labor. In addition to maternal age and residential area, parity and smoking behavior were also proven to have no relationship with preterm birth.

\section{Suggestion}

There are various kinds of programs suggested by the World Health Organization to 
reduce preterm birth rates. As Indonesia has implemented several programs in line with WHO's program, it should be doing better in increasing public awareness of the risk factors associated for preterm birth, thus slowly reducing the preterm birth rate. Efforts to accomplish may involve socialization, education, and monitoring of maternal health care program during pregnancy through the Antenatal Care (ANC) program. Pregnant women should also monitor their frequency and schedule of ANC visits to maintain maternal and child health during pregnancy.

\section{REFERENCES}

Anasari, T. and Pantiawati, I., 2016. The Relationship between Work and History of Preterm Labor and the Incidence of Preterm Labor at Prof. Dr. Margono Soekarjo Purwokerto. The 4th Univesity Research Colloquium 2016, [online] pp.202-208. Available at: <http://ojs.akbidylpp.ac.id/>

Astuti, S., Susanti, AI and Elista, R., 2016. Description of exposure to cigarette smoke in pregnant women based on gestational age in Cintamulya Village, Jatinangor District, Sumedang Regency. Journal of Health Systems, 2 (1), pp. 22-27.

Fatimah and Nuryaningsih, 2017. Textbook of Pregnancy Midwifery Care. Jakarta: Faculty of Medicine and Health, University of Muhammadiyah Jakarta.

Herlina, Y.N., Desmiwarti, D. and Edison, E., 2016. Hubungan Stresor Psikososial pada Kehamilan dengan Partus Prematurus. Jurnal Kesehatan Andalas, 5(1), pp.129-134.

Ministry of Health, 2018. Indonesia Health Profile 2017. [online] Available at: <website: http://www.kemkes.go.id>.

Koniyo, MA, Hakim, BHA and Arsin, AA, 2012. Determinants of Premature Birth's Incidence in the Regional Hospital of Prof. DR. H. Aloei Saboe, Gorontalo City. Hasanuddin University Postgraduate.

Krisnaldi, 2009. Premature Labor. Jakarta: Medical Book Publishers EGC.

Lestari, PP, Wirandoko, IH and Apriyanto, DR, 2018. Relationship between Maternal Age at Risk and Preterm Incidence in
Urban Puskesmas Areas (Observation Study at Puskesmas Gunung Sari, Kesambi, and Jalan Kembang, Cirebon City). Journal of Health \& Medicine, 4 (2), pp. 85-88.

Maidartati and Parsaulian, P., 2015. Knowledge Description of Trimester I Pregnant Women about the Effect of Cigarettes on Fetal Growth and Development in the Gynecology Clinic of Bandung City Hospital. Journal of Nursing, III (1), pp. $38-50$.

Maita, L., 2012. Maternal Factors Affecting Premature Labor at Arifin Achmad Hospital Pekanbaru Risk Factors Incident Preterm Labor. Journal of Community Health, 2 (56), pp. 31-34.

Manuaba, IBG, Manuaba, IAC and Manuaba, IBGF, 2007. Introduction to Obstetrics Lecture. [online] Jakarta: Book Medical Publishers EGC. Available at: <https://books.google.co.id>

Manuaba, IAC, Manuaba, IBGF and Manuaba, I .. BG, 2009. Understanding Women's Reproductive Health 2nd Edition. 2nd ed. [online] Jakarta: Book Medical Publishers EGC. Available at: <https://books.google.co.id>

Meihartati, T., 2016. The Relationship between Early Childhood Pregnancy and the Incidence of Premature Labor in the Maternity Room of the Paradise Mother and Child Hospital in 2015. Darul Azhar Journal, [online] 2 (1), pp. 6670. Available at: <https://idr.uinantasari.ac.id/>

Murad, M., Arbab, M., Khan, MB, Abdullah, S., Ali, M., Tareen, S. and Khan, MW, 2017. Study of Factors Affecting and Causing Low Birth Weight. Journal of Scientific Research, 6 (2), pp. 387394.

Noriani, NK, Putra, IWGAE and Karmaya, INM, 2015. Exposure to Cigarette Smoke in the Home Against the Increased Risk of Premature Birth in Denpasar City. Public Health and Preventive Medicine Archive, 3 (1), pp. 68-73.

Paembonan, N., Ansar, J. and Arsyad, DS, 2012. Risk Factors for Premature Birth at the Siti Fatimah Mother and Child Hospital, Makassar City. [online] Hasanuddin University Faculty of Public Health. Available at: 
<http://repository.unhas.ac.id/>.

Pinontoan, V. and Tombokan, S., 2015. Relationship between age and maternal parity with the incidence of low birth weight babies. Midwife Scientific Journal, 3 (1), pp. 20-25.

Sari, TW, and Syarif, S., 2016. The Relationship between Prematurity and Neonatal Mortality in Indonesia in 2010 (Data Analysis of Riskesdas 2010). Indonesian Journal of Health Epidemiology, 1 (1), pp. 9-14.

Senewe, FP and Sulistyowati, N., 2004. The Factors Related to Delivery's Complication in the Last Three Years in Indonesia (Further Analysis SKRTSurkesnas 2001). Health Research Bulletin, 32 (2), pp. 83-91.

Sulistiarini, D. and Berliana, M., 2016. Factors Affecting Premature Birth in Indonesia:
Data Analysis of Riskesdas 2013. EJournal of WIDYA Health and Environment, 1 (2), pp.109-115.

Tepper, NK, Farr, SL, Cohen, BB, Nannini, A., Zhang, Z., Anderson, JE, Jamieson, DJ and MacAluso, M., 2012. Singleton preterm birth: Risk factors and association with assisted reproductive technology. Maternal and Child Health Journal, 16 (4), pp. 807-813.

Wahyuni, R. and Rohani, S., 2017. Factors Affecting Preterm Labor. Aisyah's Journal: Journal of Health Sciences, 2 (1), pp. 61-68.

WHO, 2012. Born Too Soon: The Global Action Report on Preterm Birth. WHO. 